\title{
Queen Christina's heroic virtue and its religious implications
}

\section{by Stefano Fogelberg Rota}

Heroic virtue is a common theme in poems and panegyrics written for royal figures during the early modern period. The same heroic arguments appear with striking insistence in the praise of Queen Christina of Sweden, both before and after her abdication, inviting further attention to this theme. Of particular interest are the heroic representations of Christina in the court ballets performed in Stockholm and in the meetings of her Accademia Reale in Rome. In this article I will therefore examine the use of heroic virtue in some poems and academic discourses written for Christina, both before and after her conversion to Catholicism, taking a particular interest in its religious implications. While the presentation of Christina's heroic virtue does not differ greatly from before and after her abdication, its propagandistic aims are reversed in her passage from a Protestant to a Catholic milieu. In the latter heroic virtue appears as intimately connected to papal authority, thanks to its importance in the canonization of saints, and is thus especially emphasized in contrast to Protestantism. ${ }^{1}$ Before I introduce the writings I intend to analyse, it is necessary to consider more closely the idea of heroic virtue and how it was perceived in the mid seventeenth century.

The main source of the idea of heroic virtue is Aristotle's Nichomachean Ethics (VII, 1145 a18-21). It is there presented as a divine virtue, somehow above human virtue, and as the opposite of bestiality. For Aristotle the heroic is an attribute that concerns only the most excellent individuals. Heroic virtue is an extraordinary quality that enhances all other virtues, being a means by which man is able to approximate the divine. Thomas Aquinas, in his commentary on the Nichomachean Ethics, stresses heroic virtue's conscious and rational aspects. For Aquinas it does not actually cause man to transform into a superhuman being, but gives him a sort of pre-eminence

$1 \quad$ On the importance of heroic virtue in a catholic context see Marina Caffiero's works: "Tra modelli di disciplinamento e autonomia soggettiva" in Modelli di santità e modelli di comportamento, (eds.) Giulia Barone, Marina Caffiero, Francesco Scorza Barcellona (Rosenber \& Sellier: Torino 1994) and La politica della santità. Nascita di un culto nell'età dei Lumi (Laterza, Roma-Bari 1996), as well as Romeo De Maio, "L'ideale eroico nei processi di canonizzazione della controriforma" in Riforme e miti nella Chiesa del Cinquecento (Guida Editori: Napoli 1973) 257-78. On Queen Christina's interest for heroic virtue see also Stefano Fogelberg Rota, Poesins drottning: Christina av Sverige och de italienska akademierna (Nordic Academic Press: Lund 2008). 
over the larger part of men. ${ }^{2}$ Due to these characteristics the heroic was often to be used in the early modern period to describe an ideal and exclusive image of man, especially relevant to the self-fashioning of aristocrats and royals; traits that made it particularly well-suited to late sixteenth century Neo-stoicism. Heroic virtue thus came to be particularly prominent in the context of courtly society. Catholics and Protestants were to adopt it, as I will discuss, both for similar and very different reasons. I will therefore present heroic virtue's role in some works from the time before Queen Christina's abdication and confront them with the heroic claims put forward in poetry and panegyrics written after her conversion.

The first text I will take into consideration is the libretto of the ballet Le Monde Reioivi staged on the 1 of January 1645 to celebrate the beginning of Christina's reign. A short prose text describes heroic virtue's character as it appears on stage as one of the personages of the ballet:

Cette vertu hérö̈que, \& l'honneurs viennent ensemble pour accompagner Christine \& rendre son Regne aussi glorieux que le fût celui de Gustave, qui ne resolut iamais rien sans la prudence, n'executa rien sans la Justice, ne fit aucune action qui ne fût avouée par la vertu hérö̈que $[. . .]^{3}$

Heroic virtue acts in accordance with wisdom (prudentia) and justice (iustitia) - with courage (fortitudo) and moderation (temperantia) the four cardinal virtues - to enhance these qualities to a royal status. The heroic serves here to underline the continuity between Christina's reign and her father's, Gustavus Adolphus. Her sovereignty should be guided, as his was, by reason with which earthily passions are transcended. Some so-called vers pour les personages, non-recited verses ascribed to heroic virtue's character, follow this first description:

2 Thomas Aquinas, Commentary on Aristotle's Nicomachean Ethics (St. Augustine's Press: Indiana 1993), Iacopo Costa, "Heroic virtue in the Commentary tradition on the Nicomachean ethics in the second half of the thirteenth century" in Virtue Ethics in the Middle Ages. Commentaries on Aristotle's Nicomachean Ethics, 1200-1500 (Brill: Leiden, Boston 2008) 162.

3 "This heroic virtue and the glories come together to follow Christina and render her Reign as glorious as that of Gustavus. He that never decided anything without prudence, never executed anything without Justice, never engaged on any deed that was not counselled by heroic virtue [...]". Le Monde / Reioivi / Balet, / Dansé pour la Regence de sa Maiesté, à Stockholm / le premier de Janvier de / l'Année 1645. 
La Vertu Heroique.

[...]

Une fille à présent vient de remplir sa place

Elle va soutenir le sceptre de sa race,

Marchant sur le sentier de ses faicts glorieux

Son invincible Estat espere en sa jeunesse, Et l'on remarque en elle une haute hardiesse,

Digne du sang suedois, digne de ses Ayeux,

Ses rares qualités la rendent adorable.

Je veux, honneur, je veux en estre inséparable,

Ie veux estre l'appui de ses Intentions

Et qu'elle soit l'amour des autres nations

Que de ses Ennemis l'insolence elle brave

Et qu'elle fasse voir enfin par son grand coeur

Qu'elle est fille, mais de Gustave,

Et qu'elle porte au sein une masle vigueur. ${ }^{4}$

The young queen stands in these verses as the worthy heir of king Gustavus by means of a "male strength" that makes her virtuous. The continuity between the reigns is reiterated also later in the ballet when Christina is exhorted to continue Swedish military action in Germany. ${ }^{5}$ Heroic virtue appears as one of the pillars on which Christina's reign is grounded. Similar messages were conveyed in practically all ballets staged during her reign to affirm propagandistically some of her political stances. In particular the performances of three impor-

$4 \quad$ "A girl comes now to take his place / she will keep up the sceptre of his race, / marching on the path of his glorious deeds, / his invincible State relies its hope on her youth, / and a great bravery is to be observed in her, / worthy of her Swedish blood, and of her ancestors, / her exceptional qualities make her adorable. / I want, honour, I want to be inseparable from her, / I want to be the support of her Intentions / and that she be loved by the other nations / that she punishes the insolence of the Enemies / and that she demonstrates with her big heart / that she is a girl, but Gustavus', / and that she bears in her breast a male strength.”. Le Monde Reioivi.

$5 \quad$ On Le Monde Reioivi and the theme of the war see Stefano Fogelberg Rota, "War and peace in the court ballets performed during the reign of Queen Christina of Sweden (1644-54)" in Seventeenth century ballet: a multi-art spectacle, (ed.) Barbara Grammeniati, pp. 112-130. 
tant ballets between 1649 and 1651 - Le Vaincu de Diane, La Naissance De La Paix and Le Parnasse Triumphant - would establish the image of the queen as a superior creature devoted to reason and raised over passions, modelled on the exempla of the ancient goddesses Diana and Pallas Athena. ${ }^{6}$ Christina's refusal to marry found thus its moral and rational explanations.

A similar view on the Swedish queen's virtue is presented in Ottavio Ferrari's Pallas Svecica from 1651.7 Christina's love for learning is of course the main theme and the motive for the comparison with the goddess of wisdom. Ferrari starts off from the horatian topos of poetry as the protector of great persons' memory to praise the queen's interest in every branch of knowledge. ${ }^{8}$ For Ferrari, after

$6 \quad$ On these ballets and the propagandistic messages conveyed in them see Stefano Fogelberg Rota, "L'introduzione del balletto di corte in Svezia" in Mélanges de l'École Française de Rome (forthcoming, 2012:2). See also Lars Gustafsson, Amor et Mars vaincus: Allégorie politique des ballets de cour de l'époque de la Reine Christine in Queen Christina of Sweden. Documents and Studies, (ed.) Magnus Von Platen (Nationalmusei skriftserie, 12; Analecta Reginensia I, Stockholm 1966) 87-99 and Gunilla Dahlberg, The theatre around Queen Christina, in Renaissance Studies, XXIII, n. 2, 2009, 161-185.

7 Ottavio Ferrari, Pallas Svecica panegyricusa Christinae, Gothorum, Vandalorum, ac Suecorum reginae imperium auspicanti dictus, Venetiis, Ex typographia Ducali Pinelliana, 1651. Ottavio Ferrari was a professor in rhetoric in Milan and Padua and came later to write even a second panegyric for Christina in occasion of her abdication, Christina abdicans, Patavii, typis Pauli Frambotti bibliopolæ, 1654. He had previously dedicated at least another composition to Gustavus Adolphus. Ferrari's panegyrics are analysed by Iiro Kajanto in Christina Heroina. Mythological and Historical Exemplification in the Latin Panegyrics on Christina Queen of Sweden (Annales Academiae Scientiarum Fennicae, Suomalainen Tiedeakatameia, Helsinki 1993).

$8 \quad$ Ferrari's praise of Christina's patronage is in its turn praised by the queen in a letter from 1 December in which she invites him to compose more on the subject "J'ai temoigné, il y a déja longtems, par le petit présent que je vous ai fait, que le panégirique dans lequel vous avez donné au Public, à l'ombre de mon nom, l'image d'une bonne Princesse, ne má nullement déplu. [...] J'avoue pourtant, que de tels complimens vos semblables, me sont \& seront toûjours fort agréables. Car qu'est-ce que qui pourroit me donner plus de plaisir que de reconnoitre, que les soins que je donne tous les jours à l'avancement \& a l'honneur des belles letters, ne sont pas désaprouvés de ceux de qui elles empruntent le credit \& la consideration, dont elles jouissent?" (I testified, already for a time ago, with the small present I sent you, that I appreciated the panegyric in which you showed to the public, in the shadow of my name, the image of a righteous Princess [...] I can therefore assure you that such compliments as yours are, and will always be, very pleasing to me. Because, what could give me more pleasure than to acknowledge that all my everyday cares I give for the improvement and the honour of poetry and literature, are not disapproved by those who profess 
having settled Europe's peace with the treaty of Westphalia (1648) Christina now wants to conquer the kingdoms of art and poetry. By means of a hyperbole, he explains further how her love for studies lies behind her decision not to marry. Ferrari describes how Christina triumphs over love with the help of learning, and how she could easily put aside her crown for the Muses, if this was not to ruin the benefit of her subjects:

[...] parata etiam, sceptrum ipsum ac diadema donare Musis, si tam salvi fine te esse possent populi, quam tu privata.

Christina's virtue in Ferrari's praise is probably to be considered only as potentially Heroic. For the sake of her subjects' benefit she is constrained not leave the crown for the higher goal of learning, nonetheless she acts heroically putting aside her own inclination. After this prediction of Christina's abdication Ferrari goes on by describing how all of her qualities were even more admirable since she is a woman who has managed to overcome the weakness of her sex. The etymologically male virtus can therefore apply exceptionally to her.

[...] ipsas quoque naturae leges ac sexus imbecillitatem supergressa, tanto virorum laudes excessisti, quanto admirabilior semper in muliere virtus visa est. ${ }^{10}$

A striking characteristic of Ferrari's panegyric is the very rare references to Christina's religion. Though this apparently seems logic, due to the fact that the writer is a Catholic praising a, at that time, Protestant queen, this is nonetheless a remarkable fact. Ferrari's most complete focus on the excellence of Christina's learning excludes practically any

these?". Johan Arckenholtz, Mémoires concernant Christine Reine de Suède, pour servir d'eclaircissement à l'histoire de son regne et principalement de sa vie privée, et aux evenemens de l'histoire de son tems civile et litéraire: suivis de deux ouvrages de cette savante Princesse, qui nont jamais été imprimés. vol. I, Pierre Mortier, AmsterdamLeipzig, 1751-1760, 300-01.

9 "[...] you were even ready to give up the sceptre and crown to the muses, if the people's benefit could be held as good as yours in private.". Pallas Svecica, 278. I am grateful to Lars Fredrik Janby for his help with the translation from Latin of my quotes from Ferrari.

10 " $[\ldots]$ she trascended the law of nature and of her sex, and virtue is therefore even more admirable in a woman, since she has overcome the merits by which men are judged.". Pallas Svecica, 272. 
other aspects that could logically be part of his praise. Even her role as ruler is, in a way, cast into shadows by her love for learning.

Ferrari's stance is partially reversed in an epistle in verses by the English poet Andrew Marvell (1621-78): A Letter to Doctor Ingelo, then with my Lord Whitlock, Ambassador from the Protector to the Queen of Sweden from 1653. Marvell's epistle was written to comment upon a portrait of Christina, sent by her to Cromwell on the occasion of Bulstrode Whitelocke's (1605-75) embassy to Sweden, and is addressed to Nathaniel Ingelo (1621-83), Whitelocke's chaplain on this mission. The letter shows some interesting features for the study of the image of the queen before her abdication, and establishes a similar requisite of virtue as Ferrari's. This virtue appears as connected with heroic manners, even if these are not directly referred to. Sergio Rufini has closely studied Marvell's composition in an article. ${ }^{11}$ Rufini notices how the first part of the epistle is structured along a series of classical exempla introduced to enhance Christina's virtues. The second part focus, on the other hand, on a Christian reformed context in which Marvell significantly compares Christina with Elisabeth I. Apart from the more obvious similarity between the two queens at the time for the epistle: both women sovereigns, protestant, unmarried and devoted to learning. Marvell describes Christina as Astrea, the virgin goddess of justice that ascended to heaven at the end of the Golden age to become the constellation of the Virgo, and one of the most recurrent examples for Elizabeth. Marvell refers to Vergil's prophesy in his fourth Eclogue in which Astrea turns back to earth. The identification of Christina as Elizabeth's heir is of course an acknowledgment of her important role for the protestant cause. ${ }^{12}$ Christina's divinization is an important theme also in Marvell's composition in which it is connected to her royal status, as it appears clearly in the following verses that refer to her figure in the portrait sent to Cromwell:

11 Sergio Rufini, “'Umbrae' i 'Carmina Romulae' di Andrew Marvell per la Regina Cristina di Svezia" in Cristina di Svezia e la cultura delle accademie, (ed.) Diego Poli (Atti del Convegno Internazionale, Macerata-Fermo, 22-23 maggio 2003; Editrice "il calamo": Roma 2005) pp. 63-116.

12 This comparison appears even more interesting if we bear in mind that Christina probably disliked it as she, in her autobiography, explicitly omits Elizabeth when she criticizes female rulers in general; a position she reiterated often in different circumstances. Kristina, Brev och skrifter, red. Marie Louise Renata Rodén (Atlantis: Lund 2006). 
Vidimus Effigiem, mistasque Coloribus Umbras:

Sic quoque Sceptripotens, sic quoque visa Dea.

Augustam decorant (raro concordia) frontem

Majestas et Amor, Forma Pudorque simul. ${ }^{13}$

Christina is presented here as a goddess ruling according to virtue. In this first part of the epistle Christina's image has a pagan allegorical character, often used in panegyrics directed to kingly persons. Christina ascends to a godlike condition by the means of all her virtues. Marvell embeds this antique strain, unlike Ferrari, with a religious stance to support the case of Protestantism. If the rest of the first part of the composition focuses on the image of Christina as Pallas and Diana, in the second Marvell shifts his focus and concentrates on a more personal aspect, underscoring the richness of Christina's interior life:

\section{Quemque tenet charo descriptum Nomine semper,}

Non minus exculptum Pectore fida refert.

Sola haec virgineas depascit Flamma Medullas,

Et licito pergit solvere corda foco.

Tu quoque Sanctorum fastos Christina sacrabis,

Unica nec Virgo Volsiniensis erit. ${ }^{14}$

Christina's name is brought together with the name of Christ and she is compared, a bit surprisingly, to Saint Christina of Bolsena who died as martyr around the year 200 A.D. The process of divinization Marvell is here alluding to appears, in fact, in the context of Christian reformed confession. The metaphors introduced by Marvell are in

13 Andrew Marvell, The Poems \& Letters, (ed.) H.M. Margoliuth (Oxford: Clarendon Press, 1952) 100. "I saw her limn'd, with chequer'd light and shade / E'en in her picture seem'd she goddess-maid!/ Upon her brow (rare harmony!) there move/ Modesty, Beauty, Majesty and Love". All translations to English from Marvell's epistle are by Alexander Balloch Grosart.

14 "And Him, Christina, whose blest name thou wearest/ Graven within thy faithful heart thou bearest./ On this pure flame her virgin soul is fed,/ Before this fire her inmost heart outspread. / Thou too, Christina, hast thy saintship won; / Bolsena's maid bears not the palm alone." Marvell, The Poems \& Letters, 101. 
this second part of the epistle more abstract and refer mainly to the Holy Scripture. Marvell is more explicit towards the end where he clears his religious and political stance referring to Cromwell and the protestant struggle. Christina is an example to follow, and the English protector's hope for an ally against the imperial eagle and the Catholic Church, described as a wolf:

Discite nunc Reges (Majestas proxima caelo)

Discite proh magnos hinc coluisse Deos.

Ah pudeat Tantos puerilia fingers coepta,

Nugas nescio quas, et male quaerere Opes.

Acer Equo cunctos dum praeterit ille Britanno,

Et pecoris spolium nescit inerme sequi.

Ast Aquilam poscit Germano pellere Nido,

Deque Palatino Monte fugare Lupam. ${ }^{15}$

Christina would never join Marvell's hoped for alliance with Cromwell, but nonetheless a commerce treaty was signed in April 1654 establishing free commerce between England and Sweden. Only a year after she would abjure Protestantism and make her triumphal entrance as a catholic in Rome on the 23 of December 1655.

Praises of Christina's heroic virtue would not diminish after her arrival in the papal state and so her interest for the subject. Christina would promote in her role as patron in Rome similar poetical representations of the heroic. Cardinal Francesco Albizzi's opening discourse for the queen's Accademia Reale, founded in 1674, is a clear example. Albizzi sets out to investigate the origins of heroic virtue, its merits and man's conditions for a virtuous life. The cardinal takes two writers as guides for his undertaking: Aristoteles and Torquato Tasso; the former because of his treatment of the subject in the Nichomachean Ethics and the latter because of his heroic poetry in the epos Gerusalemme liberata. In accordance with the audience, in which a great 15 "Learn then, ye kings, whom Heav'n has raised on high,/ From this example, God to glorify:/ Blush, being great, to compass childish things,/ Vain trifles, and the wealth which sorrow brings;/ See our brave British horseman pass them all,/ No spoils of unarm'd flock before him fall, / - Fluttering the eagle in his German pine,/ Driving the she-wolf from the Palatine.". Marvell, The Poems \& Letters, 1012 . 
number of cardinals were present Albizzi develops the theme from a Christian point of view:

Mà si come se[m]pre stimai dura, e faticosa impresa il raggionare nel Publico cospetto d'Huomini Savij, e Letterati, percioche attenti essi non meno all'attione, alle parole, che à gl'accenti dell'Oratore, lo fanno bersaglio d'una Critica Censura, e d'un rigorosissimo Sindacato; cosi temo che possa avvenire à me che sono astretto di raggionare in questo si Regio, e Maestoso Teatro, alla presenza vostra magnanima Reina, che dotata di sublimi, et Heroiche Virtù, non più come Donna mortale, mà come Dea Celeste siete dal Mondo honorata, riverita, et adorata, e nel cospetto vostro Purpurati Heroi, che per l'Eminente Dignità ch'in voi risplende siete uguagliati à $i$ Regij, e per la virtù ch'in voi fiammeggia siete di già trasformati in Semidei. ${ }^{16}$

The ideal of heroic virtue is, for Albizzi, Queen Christina herself. She incarnates this virtue and is thus both the origin and the goal of his speech. The heroic is here adapted to the Christian audience of the speech, the cardinals of the Sacred College transforming by means of this particular virtue in "demigods". Albizzi approaches his subject primarily from its religious implications and lingers only rarely on epic, knightly aspects. This strategy appears clearly in the exempla he introduces to support his arguments. He mentions among others Socrates for his constancy, Augustus, Alexander and Caesar for their clemency and Diogenes for his noble soul. The heroic manifests itself in the form of self-sacrifice guided by the individual's will to operate for the good. Heroic virtue is therefore invested with the meaning of an act of generosity aiming at a definite greater goal. All Albizzi's

16 Discorso Accademico dell'Em.mo Sig.r / Cardinal degli Albizzi per l'appertura della / Regia Accademia della M.tà di Svezia (Biblioteca Apostolica Vaticana, Urb. Lat. 1692) f. 46 r. "I have always found a difficult and tiring task to speak in front of the public view of Wise and Learned Men, because they are so observant not only of the Orator's gestures and words but even to his accents and make of him the target of their Critique and their rigorous Judgement. The same I am afraid could happen to me, invited to speak in this Kingly and Majestic Theatre, in front of you, magnanimous Queen, that, endowed with sublime and Heroic Virtues, no longer lives in the condition of a human, but as a Celestial Goddess, honoured and loved by Everybody, and in front of you, Purple clothed Heroes, that for the eminent dignity that illuminates you are equal to Kings, and for the virtue that burns in you, you are already transformed in Demigods.”. For a further analysis of Albizzi's discourse see Fogelberg Rota (2008) 95-106. 
arguments are meant to introduce the foremost action illustrating heroic virtue, i.e. Christina's offer of the throne for the Catholic faith. Heroic virtue appears most evidently and is most effective when it operates together with caritas (love), the greatest of all Christian virtues. Albizzi's closeness to 17 th century neo-stoical arguments is here evident. Christina is described as a great soul, steadfastly raised over all human egoism and passion.

It is noteworthy to stress how heroic virtue had gained importance, at the time for Albizzi's discourse, in beatification and canonization processes, something attested by Lorenzo Brancati da Lauria's discussion on its voluntary dimension in his De virtute Heroica from 1668. ${ }^{17}$ Since the 1620 s heroic virtue had been the subject of discussion in the codification of canonization processes started by pope Urban VIII, Maffeo Barberini (1569-1644). ${ }^{18}$ This debate was characterised by apologetic standpoints against Protestantism and had a certain importance in limiting the distance between humanism and Counter-Reformation theology. Heroic virtue was used to claim man's limitless possibilities thanks to free will. The heroic became thus an important benchmark to determine sanctity's degree of excellence, to the point that saints were considered as personifications of this virtue. Excellent deeds and miracles had of course an important place in these discussions, but Heroic virtue was supposed to appear even more in the capacity of acting spontaneously and easily on a higher moral level. A fundamental point was the intended saint's contempt for worldly matters, an essentially anti-humanistic position that was overlooked. $^{19}$

The Christian dimension of Albizzi's speech is probably clearest in the following quote in which the cardinal laments having started his inquiry in antiquity while Christina's heroic virtue surpasses that of the antique heroes because of its connection with Christian caritas:

17 Lorenzo Brancati da Lauria, "De virtute Heroica" in Commentaria / Fr. Laurentii Brancati / De Laureaea / Ordinis Minorum Conven. S. Francisci / Universit. Rom. Professoris Theologi, SS. Congrega. Indul. ac / Reliq. Rituum, \& S. Officij Consultoris., \& Qualificat / nec non episcoporum Examinatoris. I InTertium Librum Sent. / Mag. Fr. Ioannis Duns Scoti / Eiusdem ordinis. / Tomus secundus. / In quo continentur / disputationes XXXII. / De virtutibus in genere; / De quatuor Cardinalibus, earumq; speciebus; \& de Haeroica, / Romae, Ex Typographia Haeredum Corbelletti / M.DC.LXVIII, 709-826.

$18 \quad$ Caffiero (1994) 265 and Caffiero (1996) 46.

19 De Maio (1973) 257-78. 
A che io mi vò male aveduto che sono trà le affumicate Pitture dell'Antiche memorie cotanto raggirando, basta che io additi Voi Sacra Reina, le cui heroiche virtù [...] come incantata langia li più Vigorosi Aversarij stenderà vergognosamente al Piano, anzi che si come il vostro Heroico Splendore, e p[er] rispetto dell'ultimo fine chè Dio, e la Vita imortale, il Cielo, et in riguardo al fo[n] damento della vostra Carità, che non meno vi accende il Petto, che vimporpori il Manto, cosi con la sola Prese[n]za di voi medesima rimane affatto d'ogni dubitatione dileguata ogn'ombra, e dibarbata ogni radice, e per dire il vero non puo essere punto ordinaria quella Virtù che vi rende tanto veneranda ovunque scalda il Sole, perche in quella maniera, che no[n] ogni Stella, mà quelle che con più dovitia saettano i raggi, e i lampi, à se tirano la Vista cupidissima de Mortali; nella stessa guisa non il Commune, non il volgare adoprar virtù, mà l'Augusto, l'Heroico, il Divino, è quello che in Secolo sì fortunato induce stupore, e maraviglia l'haver voi con fatto più che Eroico abbandonati i Regni, e gl'Imperi, no[n] già, come il miscredente Diocletiano per menar vita otiosa, e negletta; mà per correr humilmente ad adorare i Sepolchri Sacrosa[n]ti del Vaticano, l'haver involato alla Regia Chioma pretiosa treplicate Corone, et alle degne mani i scettri temuti per depositarli à i piedi della Gran Madre d'Iddio; Chioma ben più degna d'esser riposta frà le stelle, che la favolosa di Berenice. ${ }^{20}$ Christina's example shines over the audience and exhorts to similar deeds. The queen acts as a goddess, or better as a saint. Her heroicity invites to take up the fight against some unspecified but still very clear enemies. Heroic virtue, intimately connected to the cult of the saints and to papal authority, is for Albizzi and for the other theologians of the time, the main weapon to be used against Protestant heresy. This does of course not mean that Albizzi was preparing for a

20 "But why am I wandering on wrong paths among Antique Images enveloped by mist? It would be enough to indicate You, Sacred Queen, whose heroic virtue $[\ldots]$ as an enchanted spear will vanquish in shame the Strongest Enemies. Your Heroic splendour will, furthermore, with respect for the outermost goal that is God, and for the eternal Life, Heaven, and for that Love that lights your Breast and colour with purple your Mantle, disperse all doubt and drive away all shadows, and eradicate all roots. Truly, that Virtue that make you so glorious everywhere the Sun shines can hardly be considered of a common kind. In the same manner as only the brightest Stars attract the most desiring Gazes is your Virtue not of the vulgar, nor of the Common kind, but Majestic, Heroic and Divine. In such a happy Century it inspires to marvel to see how you surpassed even the Heroes and left your Kingdom and your Power, but not for an idle life, but to come in humble admiration of the Holy Graves in the Vatican after that you removed the three Crowns from your precious Kingly Hair, more worthy to be in heaven than Berenikes."

Discorso Accademico dell'Em.mo Sig.r / Cardinal degli Albizzi, f. 51 r-v. 
future canonization of the queen. The execution of Giovanni Rinaldo Monaldeschi (1629-1657), for his supposed betrayal of Christina's plans for a coup d'état in Naples, and her unconventional manners were real obstacles for this. ${ }^{21}$ Albizzi's aims with his discourse were rather to exhort Christina's academicians to act in the tradition of early renaissance academies for a moral elevation through knowledge, something that appears as the main proposition for Accademia Reale's philosophical and poetical activity. The claim for heroicity stands as a programmatic position for Christina's academy in one of the first statutes written by the queen in which she declares that

La prima Accademia publica che si farà sia tutta diretta alla lode delle grandi ed heroiche virtù del sommo Pontefice, in augurarla sotto i gloriosi Auspicj della Santità Sua. ${ }^{22}$

It is therefore not surprising to notice that at least another discourse put forward in Christina's Academy was dedicated to Heroic virtue and that several planned meetings were to discuss the same topic. ${ }^{23}$ Claiming heroicity appears as Christina's strategy to unite in her Academy Neo-stoic influences with Catholic theology, in opposition to the Protestantism she had abjured. To paraphrase the title of Svens Stolpe's book on Christina's maxims, Från Stoicism till mystik (From Stoicism to Mysticism) Christina's use of heroic virtue evinces both Neo-stoicism and Christian thought, at the same time. ${ }^{24}$

Finally Christina's interest for the heroic is attested even in

$21 \quad$ Curt Weibull, Drottning Christina och Monaldesco (Natur och Kultur: Stockholm 1936). Curiously Christina nonetheless refers in a letter from Hamburg to cardinal Azzolino how a certain father Fonzio was "loosing his time praying to God that I will become a saint". Kristina, Brev och skrifter, 130.

22 "The first public Academy gathering will be devoted to the praise of the Pope's exceptional and heroic virtues, as it is inaugurated under His Holiness glorious protection”. Fogelberg Rota (2008), 97.

23 This second discourse on heroic virtue, Anonymi recentioris tractatus de virtute heroica, is discussed in Fogelberg Rota (2008) 106-17 and a list over topics to be discussed in later meeting of the Academy is printed at p. 372 .

24 Stolpe's argument that Christina gradually abandoned her Neo-stoical view and at the end of her life, long after her conversion, was influenced by Christian mysticism appears thus groundless. Eva Haettner Aurelius has already put into question Stolpe's view on this topic in her Inför lagen - kvinnliga svenska självbiografier från Agneta Horn till Fredrika Bremer (Lund University Press: Lund 1996) 113-188. 
some of her poetical statements, as for instance her appreciation for the poetry of Vincenzo da Filicaia (1642-1707) in a letter written in 1684 on the occasion of the publication of the poet's canzone for the Christian victory at the siege of Vienna. Christina considers here how Alexander the great would envy more her and the kings of her time, for they disposed over Filicaia's praise, than he did with Achilles that disposed over Homer. Apart from this and other similar hyperboles Christina states two important points. First about his style:

Voi avete dell'arte, dell'ingegno, del giudizio, e del sapere, e maneggiate il sacro, ed il profano da Maestrone: è bellissimo, e purissimo il vostro stile: le vostre fantasie, e figure sono nobili, e sublimi; non finirei mai se io volessi dirvi tutto quello, che io ne sento. Il Signore Iddio con prosperar sempre più l'armi de' Principi Cristiani vi faccia diventare così gran Profeta, quanto siete un Poeta incomparabile. Da voi solo può sperare il nostro secolo la gloria d'un Poema eroico uguale a quello del gran Tasso. ${ }^{25}$

Christina refers here to that developing Arcadian poetics founded on clarity of language and decorum that would breakthrough first in 1690, the year after Christina's death, with the foundation of the Accademia dell'Arcadia after the suggestions of the queen's Academy. Moreover, we should take care to note the moral strain that according to the queen should be poetry's foundation; a morality stance that should serve the Christian armies. Some lines further down this concept his fixed when Christina declares that for this heroic poetry a "Uomo grande" (a great Man) is needed.

Stefano Fogelberg Rota

University of Stockholm

25 "You possess the art, have good judgment and knowledge, and you sing as a great Master both holy and profane themes. Your style is very beautiful, and pure. Your fantasies are noble and sublime. I could never stop if I hade to tell you everything I feel about your poetry. God almighty, which always hopes for the success of the Christian armies, let you be a great prophet as you already are an incomparable poet. Only from you can our century hope for an epos equal to the one of the great Tasso.". The whole letter is published in Fogelberg Rota (2008) 144. 